STUDIA I PRACE WYDZIAŁU NAUK EKONOMICZNYCH I ZARZĄDZANIA nr 41, t. 2

Ireneusz Miciuła*

Uniwersytet Szczeciński

\title{
SYTUACJA NA GLOBALNYM RYNKU SUROWCÓW ENERGETYCZNYCH I PERSPEKTYWY ROZWOJU DO 2030 ROKU
}

\section{Streszczenie}

Postępujące procesy globalizacji i związane z nimi rozwiązania na arenie międzynarodowej podlegają niebywałej dynamice. Jednym $\mathrm{z}$ fundamentalnych obszarów współczesnej ekonomii politycznej są rozwiązania dotyczące źródeł energii. W artykule na podstawie danych statystycznych i wnioskowania przeprowadzono badania obecnego stanu rynku surowców energetycznych oraz podjęto próbę zarysowania perspektyw rozwoju na globalnym rynku energii do 2030 roku ze szczególnym uwzględnieniem sytuacji państw europejskich.

Słowa kluczowe: surowce energetyczne, ekonomia polityczna, zrównoważony rozwój, finanse międzynarodowe

\section{Wprowadzenie}

Energia to siła napędowa gospodarek całego świata ${ }^{1}$. Dostęp do źródeł energii niewątpliwie stanowi jeden z podstawowych czynników rozwoju gospodarczego. Energetyka zyskała na znaczeniu wraz z nastaniem pierwszej rewolucji przemysłowej i od tej pory zapotrzebowanie na energię stale rośnie. Obecnie niemożliwe jest normalne funkcjonowanie społeczeństw bez stałych dostaw energii, dlatego

\footnotetext{
* E-mail: irekmic@wneiz.pl

1 http://europa.eu/legislation_summaries/energy/index_pl.htm [dostęp 10.02.2015].
} 
dostęp do surowców energetycznych stanowi aktualnie jeden z najistotniejszych problemów współczesnej gospodarki światowej. Celem artykułu jest zbadanie sytuacji na globalnym rynku surowców energetycznych wraz z prognozą rozwoju do 2030 roku, co pozwala jednocześnie na wnioskowanie w sprawie fundamentalnych problemów ekonomii politycznej w energetyce państw europejskich i wskazanie zaleceń w tych kwestiach.

\section{Aktualny stan globalnego rynku surowców energetycznych}

Współczesne ocieplenie klimatu osiągnęło apogeum około 1940 roku, a więc zanim nastąpił przyspieszony wzrost emisji $\mathrm{CO}_{2}$ ze spalania paliw kopalnych. Świadczy to o tym, że $\mathrm{CO}_{2}$ wytwarzany przez człowieka nie ma wielkiego wpływu na klimat. Warto zwrócić uwagę, że do całkowitego strumienia $\mathrm{CO}_{2}$ wprowadzanego do atmosfery człowiek dodaje swoją aktywnością przemysłową i rolniczą tylko około 3,5\% ${ }^{2}$. Jest to porównywalne do corocznych wahań całej masy $\mathrm{CO}_{2} \mathrm{w}$ atmosferze. Natomiast dodatkowo emisja $\mathrm{SO}_{2}$ pociąga za sobą odwrotne zjawisko, a więc ochłodzenie klimatu. Wynika z tego, że w skali globalnej problem ten nie istnieje, a tym bardziej nie jest konsekwencją działalności człowieka. Natomiast Światowa Organizacja Zdrowia (WHO) w 2013 roku uznała, że problem zanieczyszczenia środowiska jest zauważalny lokalnie, ale mają na to wpływ wszystkie szkodliwe związki chemiczne i pyły, które prowadzą m.in. do powstania zjawiska smogu3 ${ }^{3}$. Dlatego wbrew powszechnie sformułowanej tezie o rzekomym globalnym efekcie cieplarnianym oraz potrzebie redukcji gazów cieplarnianych i obniżenia produkcji energii z węgla świat nic sobie z tego nie robi i zużywa coraz większe jego ilości. Konsumpcja węgla praktycznie we wszystkich układach i kategoriach w ciągu pierwszych piętnastu lat XXI wieku wzrosła, i to bardzo dynamicznie, zarówno w układzie globalnym, kontynentalnym, jak i geopolitycznym. Konsumpcję węgla ograniczyły tylko te kraje Starego Kontynentu, które wyczerpały większość swoich zasobów, czyli Belgia, Francja, Wielka Brytania, czy w przypadku jedynie węgla kamiennego - Niemcy. Świat od ponad pół wieku rozwija się energetycznie w szybkim i stabilnym tempie. Ogólnie zużycie energii wzrosło od 1965 roku z 3750 do $12685 \mathrm{mln}$ toe w 2012 roku. Według prognozy dla globalnego rynku energetycznego wydajność energetyczna wszystkich światowych instalacji ma wzrosnąć z 5,640 gigawatów (GW) w 2012 roku do 9,266 GW w 2030 roku. W tym

\footnotetext{
2 http://jaron.salon24.pl/jeden-wybuch-wulkanu-i-mit-o-szkodliwosci-co2-i-emisji-pylu-upadl [dostęp 11.02.2015].

3 www.who.int/publications/en/ [dostęp 27.01.2015].
} 
samym okresie produkcja energii elektrycznej ma wzrosnąć z 22,441 terawatogodzin (TWh) do poziomu $34,458 \mathrm{TWh}^{4}$.

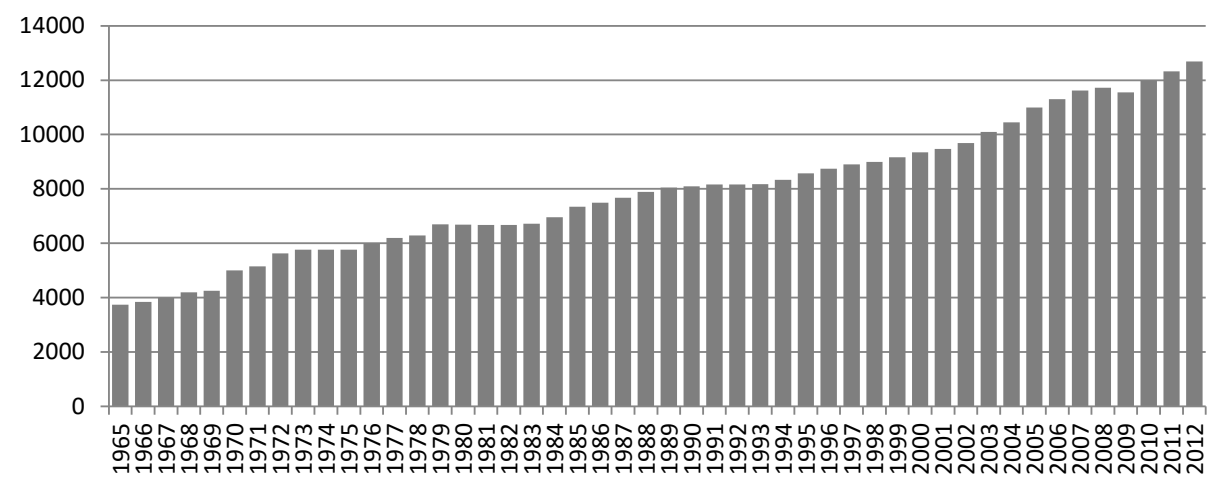

Rysunek 1. Konsumpcja energii na świecie w latach 1965-2012 (mln toe)

Źródło: opracowanie własne na podstawie Statistical Review of World Energy 2013, http://www.bp.com/en/ global/corporate/about-bp/statistical-review-of-world-energy-2013.html [dostęp 22.02.2015].

Poziomy wytwarzania energii ze wszystkich głównych trzech paliw mają być wyższe, a dodatkowo prognozy wskazują, że węgiel stanie się paliwem dominującym $^{5}$. Obecnie stanowi prawie $30 \%$ mocy istniejących instalacji, a w 2030 roku może osiągnąć poziom około $35 \%$ ilości wytwarzanej energii i globalnie ponownie stanie się głównym surowcem energetycznym. Również oczekuje się, że gaz będzie szybko nadrabiał zaległości i nabierał jeszcze większego znaczenia. Procesy te można już zaobserwować, co pokazują dane na rysunkach 2 i 3 , a spełnienie tych prognoz może nastąpić znacznie szybciej.

Obserwując współczesne doniesienia medialne, można mieć wrażenie, że odnawialne źródła energii są w rozkwicie, lecz jest to jedynie wrażenie. W statystykach zużycia pierwotnych źródeł energii w XXI wieku rzeczywistość przedstawia się całkowicie odmiennie niż w codziennych doniesieniach ${ }^{6}$. Widać, że dalej dominuje ropa naftowa, choć jej wzrost jest nikły i można zauważyć stagnację spowodowaną $\mathrm{z}$ jednej strony nasyceniem rynku, a $\mathrm{z}$ drugiej pojawieniem się alternatywy w postaci biopaliw i pojazdów elektrycznych. Dlatego prognozy do 2030 roku wskazują na mniejsze znaczenie ropy w koszyku źródeł energii i oddanie dominacji na rzecz węgla, a w perspektywie 2050 również na rzecz gazu. Najdynamiczniej rozwijające się źródło energii XXI wieku to węgiel, a za nim

\footnotetext{
${ }^{4}$ Prognozy dla globalnego rynku energetycznego, ed. H. Thaler, Frost \& Sullivan, 2014.

5 H. Dyer, M.J. Trombetta, International Handbook of Energy Security, Edward Elgar, Cheltenham 2013.

${ }^{6} \mathrm{http}: / /$ szczesniak.pl [dostęp 14.03.2015].
} 
gaz. Analizując sytuację źródeł energii od 2000 roku, można określić procentową dynamikę wzrostu zużycia poszczególnych surowców, która wynika ze zmian liczonych w mln toe. Generalnie konsumpcja energii wzrosła o 35,7\%, a wzrost poszczególnych surowców energetycznych był następujący: 70,2\% węgiel, 51,4\% gaz ziemny, $19,5 \%$ energia wodna, $16,8 \%$ ropa naftowa i $6,3 \%$ energia nuklearna.

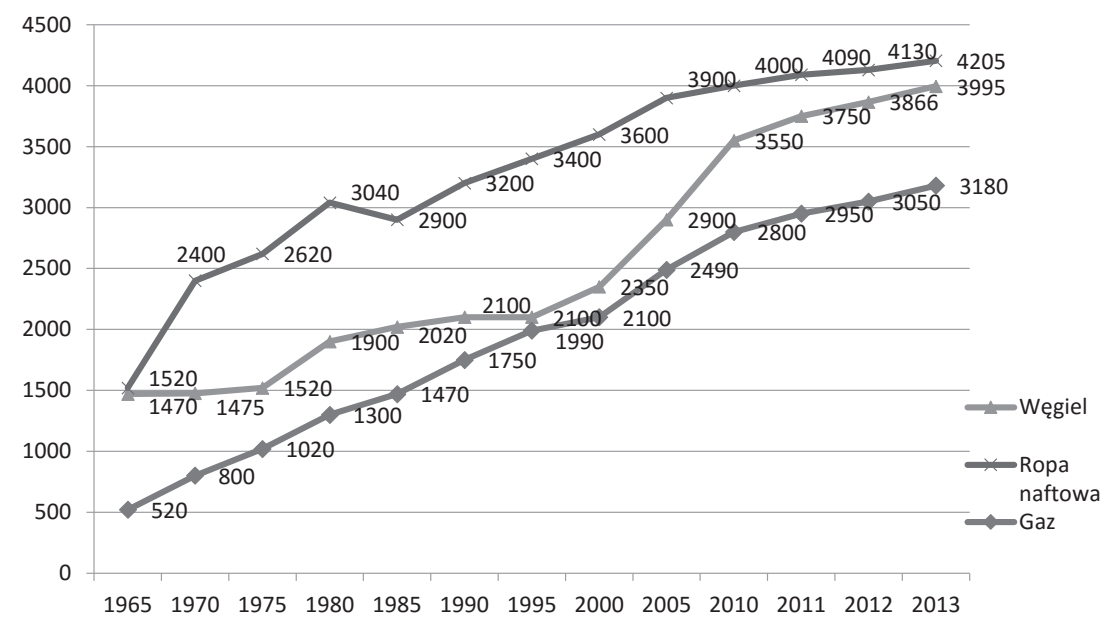

Rysunek 2. Konsumpcja trzech głównych źródeł energii na świecie w latach 1965-2013 (mln toe)

Źródło: opracowanie własne na podstawie Statistical Review of World Energy 2014, http://www.bp.com/ en/global/about-bp/energy-economics/statistical-review-of-world-energy/statistical-review-downloads.html [dostęp 22.02.2015].

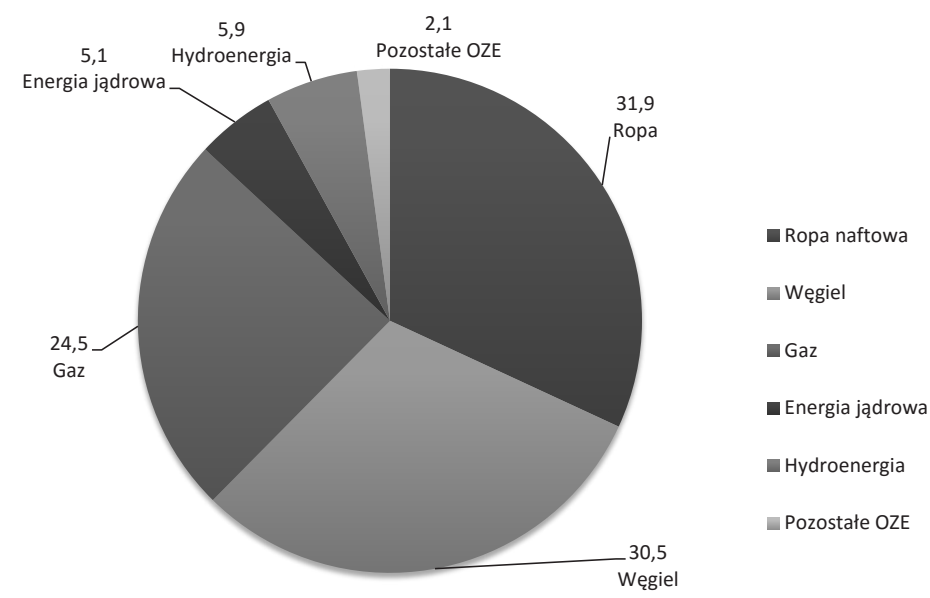

Rysunek 3. Energia z poszczególnych źródeł na świecie w 2013 roku (\%)

Źródło: opracowanie własne na podstawie International Energy Agency, Key World Energy Statistics 2014, http://www.iea.org/publications/freepublications/publication/ [dostęp 22.02.2015]. 
Wzrost koniunktury w zakresie węgla jest wynikiem potrzeby zaspokojenia w energię szybkiego rozwoju gospodarczego Chin i innych państw azjatyckich oraz wzrostu wydobycia w większości państw świata. Natomiast w przypadku gazu wynika to z zapotrzebowania na charakteryzujące się większą czystością i elastycznością systemy wytwórcze oraz ze wzrostu poziomu światowego wydobycia. Ogromny wzrost mocy produkcyjnych nastąpił w Ameryce Północnej w wyniku odkrycia bardzo bogatych złóż gazu łupkowego, a dodatkowo prognozy wskazują na szybki rozwój energetyki gazowej także na Bliskim Wschodzie oraz w Chinach7. Takie tendencje rozwojowe potwierdza rysunek 4, na którym ukazano średnie roczne światowe zużycie energii na osobę w rozbiciu na poszczególne źródła energii.

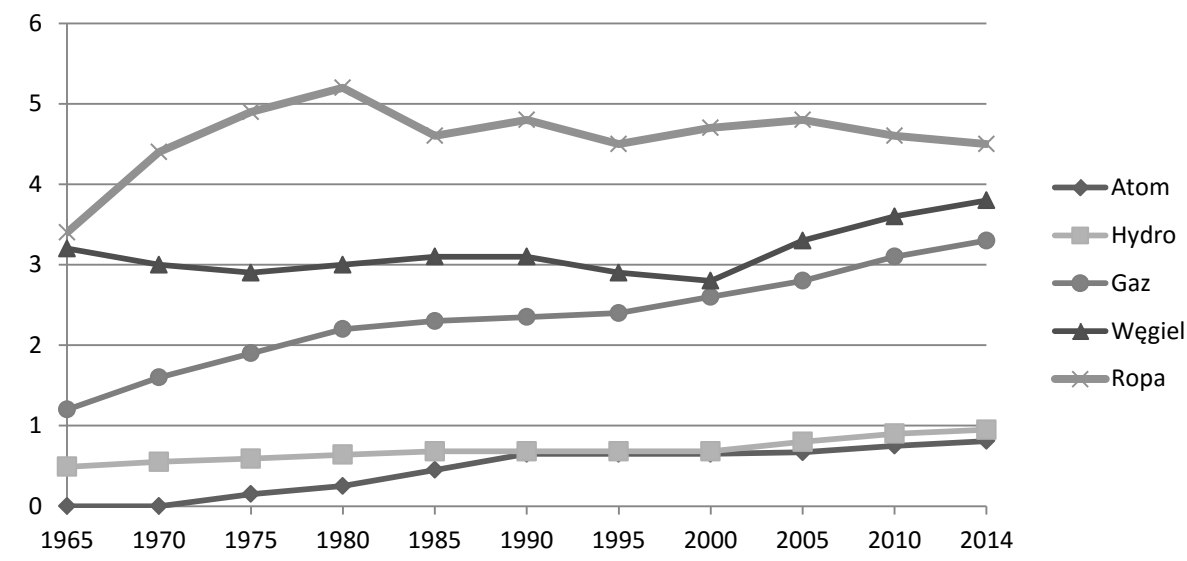

Rysunek 4. Średnie roczne światowe zużycie energii na osobę według źródła (w BOE ${ }^{8}$ )

Źródło: opracowanie własne na podstawie www.calgaryherald.com [dostęp 11.01.2015].

Zgodnie z prognozami w XXI wieku węgiel ponownie stanie się pierwszym surowcem energetycznym na świecie. Tendencję tę potwierdzają światowe zasoby węgla, które są globalnie równomiernie rozłożone i stanowią $60 \% \mathrm{w}$ stosunku do $40 \%$ łącznie dla ropy naftowej i gazu ziemnego w koszyku trzech głównych źródeł energii współczesnego świata.

\footnotetext{
${ }^{7}$ L.F. Leveque i in., Security of energy supply in Europe Natural Gas, Nuclear and Hydrogen, Loyola de Palacio series on European Energy Policy, 2014.

8 Baryłka ekwiwalentu ropy naftowej, 1 baryłka ropy $=42$ galony $=159$ litrów.
} 


\section{Sytuacja Europy na rynku energetycznym}

Europa jest coraz mniejszym graczem na światowym rynku energii. Widać to również przy analizie udziału w światowej konsumpcji trzech głównych surowców energetycznych, które najlepiej oddają trendy energetyczne Europy. Udział procentowy w konsumpcji ropy naftowej zmniejszył się z 29\% w latach 70 . do 15\% w 2013 roku. Udział gazu po gwałtownym wzroście do początku lat 80., gdy było to $19 \%$, odznaczał się długim okresem stabilności, aby po 2005 roku spaść do 14\% w 2013 roku. Natomiast największy spadek odnotował węgiel, ponieważ w 1965 roku Europa zużywała 36\% światowego bilansu, a dziś niespełna 8\%. To trwała tendencja pokazująca potrzebę konsumpcji energii w innych, szybko rozwijających się regionach świata oraz stagnację gospodarek i problemy państw UE.

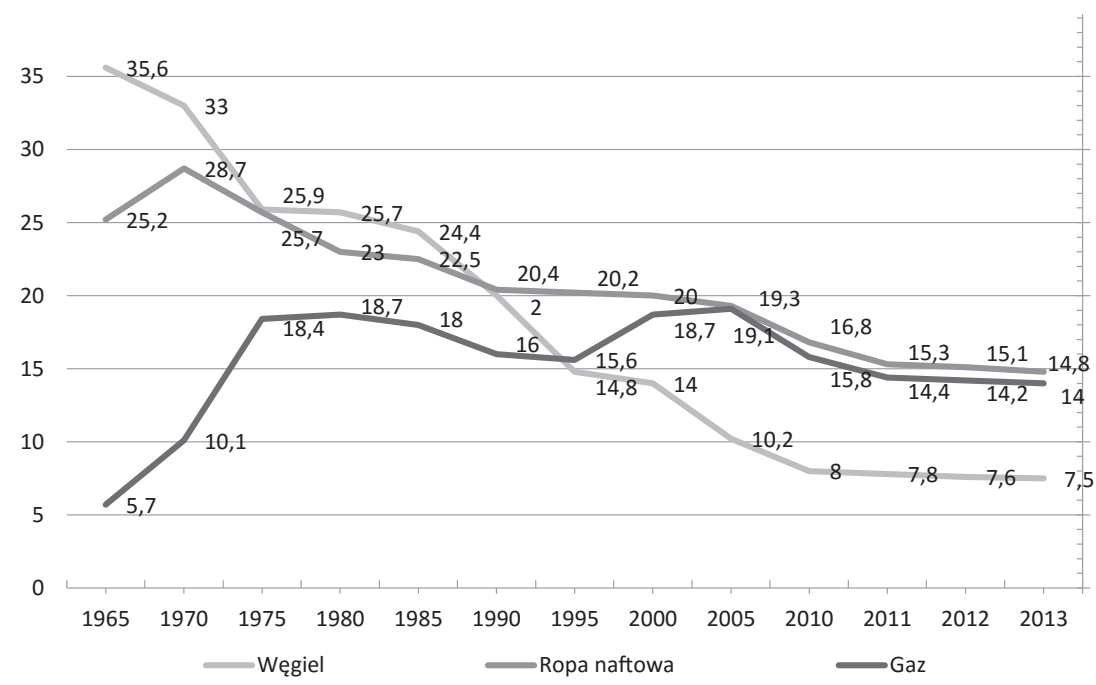

Rysunek 5. Udział Europy w konsumpcji światowej energii z głównych surowców (\%)

Źródło: opracowanie własne na podstawie http://www.iea.org/topics/Energy/Policy/news [dostęp 5.03.2015].

Analizując zasoby węgla kamiennego w państwach UE, można powiedzieć, że era jego wydobycia przy braku odkrycia nowych złóż została w sposób naturalny zakończona w wyniku wyczerpania zasobów. Należy jedynie pominąć Polskę, która w chwili obecnej dysponuje 86\% wszystkich zasobów węgla kamiennego wśród państw Unii Europejskiej.

Wnioski dla branży węglowej zarówno w kontekście świata, jak i państw UE należy wyciągać z analizy wszystkich rodzajów węgla aktualnie dostępnych, a w literaturze przedmiotu można spotkać analizy oparte jedynie na zasobach 
węgla kamiennego, które mają przełożyć się na strategiczne decyzje w polityce energetycznej. Najlepszym przykładem są państwa członkowskie UE, w których polityka klimatyczno-energetyczna, przynajmniej w teorii potwierdzonej aktami prawnymi UE, zmierza do ograniczania węgla jako surowca energetycznego ze względu na zbyt dużą emisję dwutlenku węgla. Natomiast praktyka, czyli dane statystyczne, pokazuje zupełnie co innego i mimo wyczerpania zasobów węgla kamiennego konsumpcja węgla wzrasta. Dodatkowo prognozy wskazują, że zarówno na świecie, jak i w państwach UE konsumpcja węgla będzie rosła i to pomimo polityki ograniczania tzw. brudnej energii, czyli powodującej emisję znacznej ilości gazów cieplarnianych ${ }^{9}$. Doskonałym przykładem w tej kwestii są Niemcy. Kraj, który jest w największym stopniu odpowiedzialny za kierunek współczesnej polityki klimatyczno-energetycznej UE w wyniku wywieranego wpływu partii Zielonych, jest jednocześnie największym producentem węgla w Europie, a wydobycie węgla brunatnego ma największe na świecie. Dodatkowo rozpoczęto inwestycje w budowę kolejnych sześciu kopalń węgla brunatnego, co jeszcze wzmocni Niemcy na pozycji światowego lidera. Dlatego w kolejnych latach wydobycie węgla brunatnego w Niemczech przekroczy $200 \mathrm{mln}$ ton rocznie.

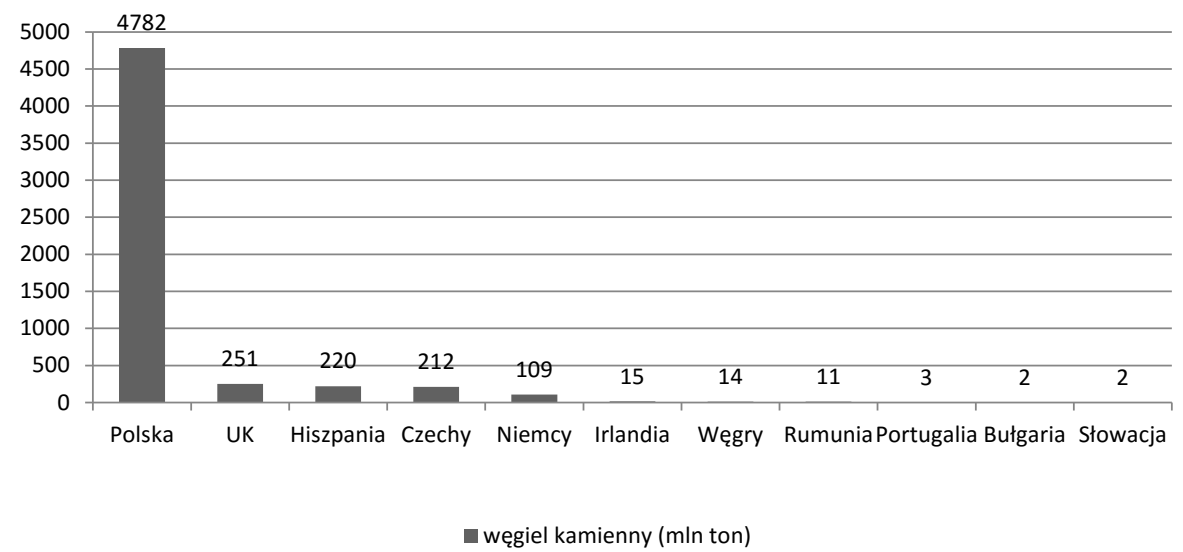

Rysunek 6. Zasoby węgla kamiennego w państwach Unii Europejskiej w 2013 roku (mln ton)

Źródło: opracowanie własne na podstawie Eurostat, http://ec.europa.eu/energy/statistics [dostęp 12.02.2015].

9 D. Moran, J. Russell, Energy Security and Global Politics, Routledge Global Security Studies, Taylor \& Francis Group, London and New York 2009. 


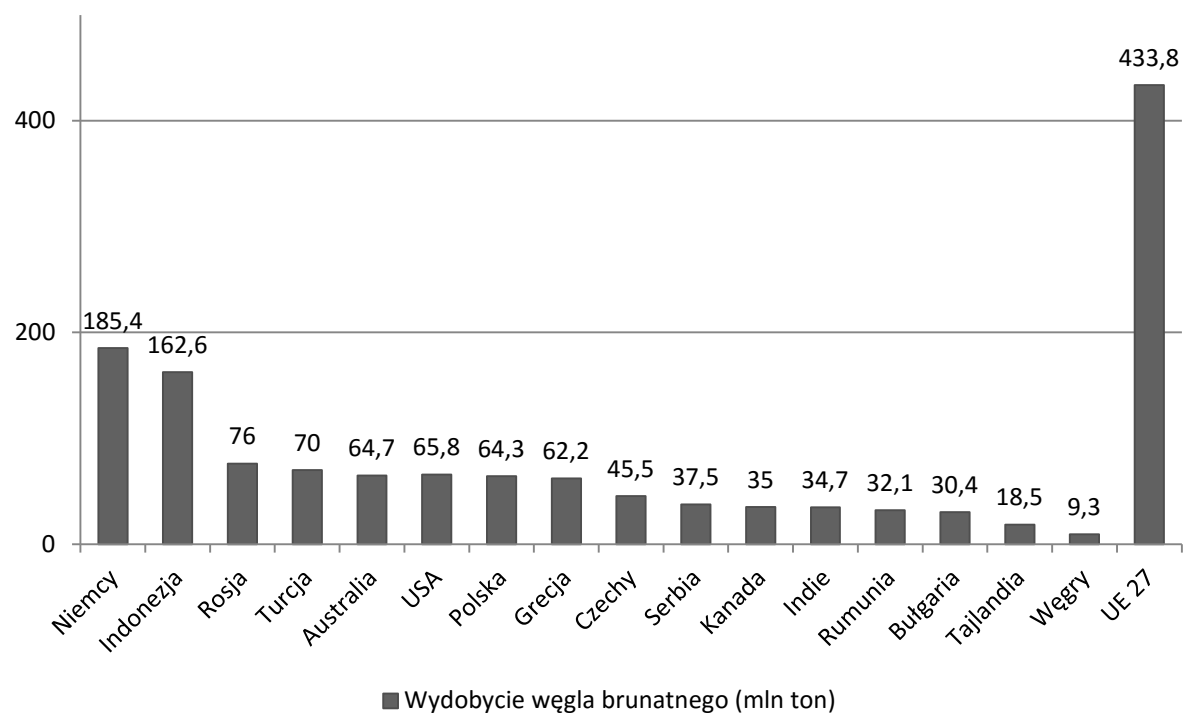

Rysunek 7. Wydobycie węgla brunatnego na świecie w 2013 roku (mln ton)

Źródło: opracowanie własne na podstawie Energy Information Administration, International Energy Annual, 2014.

W związku z powyższym strategie działań w krajach UE powinny być tworzone na podstawie inwestycji realizowanych w praktyce przez inne państwa członkowskie, w tym Niemcy, które są odmienne od ustaleń dotyczących polityki klimatyczno-energetycznej. Dodatkowo Niemcy, które wartościowo mają największy udział w emisji dwutlenku węgla wśród państw UE, wytwarzają prawie $50 \%$ energii elektrycznej z węgla, w tym ponad $30 \% \mathrm{z}$ mniej wydajnego węgla brunatnego. Ma to na celu zrównoważenie dużych kosztów zielonej energii i zapewnienie źródła prądu na wypadek wahań w produkcji z odnawialnych źródeł energii (OZE). W związku z tym realizuje się racjonalną politykę energetyczną, która jest sprzeczna z ustaleniami UE.

Jednocześnie należy zwrócić uwagę, że Niemcy wartościowo, przy pominięciu Polski, wydobywają i konsumują tyle węgla, ile wszystkie pozostałe państwa UE łącznie, dlatego wiele rozporządzeń UE, w tym te odnoszące się do wartości z 1990 roku jako roku bazowego, niewątpliwie mają prowadzić do zachowania dotychczasowych różnic wśród gospodarek państw członkowskich. Jest to niezgodne z samą ideą Unii Europejskiej i nie zostawia wątpliwości, że odbywa się cicha wojna gospodarcza, dzięki której państwa przodujące chcą utrzymać dominującą pozycję. Solidarność UE jest widoczna jedynie w sytuacji występowania wspólnych interesów na linii z państwami zewnętrznymi. Niestety, często w wyniku ich braku wiele państw UE, w tym Niemcy, przedkładają własne inte- 
resy gospodarcze nad ideę UE i podejmują się realizacji projektów sprzecznych z interesem UE i innych krajów członkowskich. Najlepszym przykładem są relacje z Rosją, które przyczyniają się do rozłamu i odmiennych stanowisk w UE. Problemy w polityce energetycznej UE wynikają z niewypracowania spójnej polityki i braku bogatych złóż głównych źródeł energii.

Tabela 1. Wydobycie węgla kamiennego i brunatnego w 2013 roku (mln ton)

\begin{tabular}{|c|c|c|}
\hline $\begin{array}{c}\text { Miejsce } \\
\text { pod względem } \\
\text { wydobycia }\end{array}$ & Państwo & $\begin{array}{c}\text { Wydobycie węgla kamiennego } \\
\text { i węgla brunatnego }\end{array}$ \\
\hline 1 & Chiny & 3730 \\
\hline 2 & Stany Zjednoczone & 996 \\
\hline 3 & Indie & 694 \\
\hline 4 & Indonezja & 575 \\
\hline 5 & Australia & 459 \\
\hline 6 & Rosja & 412 \\
\hline 7 & RPA & 291 \\
\hline 8 & Niemcy & 198 \\
\hline 9 & Polska & 144 \\
\hline 10 & Kanada & 132 \\
\hline 11 & Kazachstan & 125 \\
\hline 12 & Kolumbia & 94 \\
\hline 13 & Turcja & 81 \\
\hline 14 & Grecja & 69 \\
\hline 15 & Ukraina & 64 \\
\hline 16 & Czechy & 58 \\
\hline 17 & Wietnam & 45 \\
\hline 18 & Serbia & 39 \\
\hline 19 & Rumunia & 35 \\
\hline 20 & Bułgaria & 32 \\
\hline
\end{tabular}

Źródło: opracowanie własne na podstawie Enerdata, Global Energy Statistical Yearbook 2014.

\section{Perspektywy rozwoju źródeł energii do 2030 roku}

Na tle analizy stanu i uwarunkowań można sporządzić zarys strategii w obszarze energii w postaci zidentyfikowanych zagrożeń oraz przyszłościowych priorytetów i trendów, które będą miały największy wpływ na światowy przemysł energetyczny. Następnym aspektem sytuacji energetycznej na świecie jest sektor 
transportowy, nikt bowiem nie ma wątpliwości o ogromnym znaczeniu amerykańskiej rewolucji łupkowej dla globalnego rynku ropy naftowej. Dzięki rozwojowi tej technologii od 2010 roku w USA nastąpił wzrost produkcji ropy o 3,6 mln baryłek dziennie, a jednocześnie aż o 3,3 mln baryłek dziennie zmniejszyła się chłonność tamtejszego rynku. Kanadyjczycy dołożyli swoje 1,5 mln baryłek dziennie dzięki wydobyciu z piasków bitumicznych. Wzrost podaży ropy na świecie nie jest jednak wyłącznym dziełem Ameryki Północnej. Swoje robią także gracze z innych rejonów świata. Po wojnie na rynek z własną ropą powróciła Libia, a także wielu innych producentów średniej wielkości. Na dodatek pomimo wojny nie zmalała produkcja na Bliskim Wschodzie. Wszystko to dzieje się w sytuacji, gdy globalne zużycie ropy jest niższe o $5 \mathrm{mln}$ baryłek dziennie. Ropa od dawna nie była poddana naturalnym procesom rynkowym w takim stopniu, jak obecnie. W miarę jak samochody będą stawać się coraz bardziej ekonomiczne, zapotrzebowanie na ropę może przez wiele lat spadać, tym bardziej że najwięksi importerzy ropy, czyli USA, Europa, Chiny, Indie i Japonia, będą dążyć do złamania monopolu ropy jako źródła energii $\mathrm{w}$ transporcie drogowym ${ }^{10}$.

Silny wzrost zapotrzebowania na energię ze źródeł odnawialnych w UE wynikający m.in. z potrzeby przestrzegania postanowień międzynarodowych dotyczących zmian klimatu czy z chęci wspierania nowych branż w zakresie zielonej gospodarki ulegnie wyhamowaniu. Tempo realizacji idei globalnego społeczeństwa niskoemisyjnego pozostanie powolne. Wynika to głównie z niskiej wydajności charakteryzującej większość odnawialnych źródeł energii w porównaniu $\mathrm{z}$ energią konwencjonalną. W wyniku większego skomplikowania technologii i wad dotyczących energii nuklearnej (niebezpieczeństwo, odpady radioaktywne) i OZE (kosztowność, brak wystarczającej wydajności) prognozy wskazują, że energia $\mathrm{z}$ gazu będzie popychać światową branżę energetyczną w stronę produkcji w większym stopniu wolnej od dwutlenku węgla. Niewątpliwie już obecnie widać, że większość państw łącznie z Niemcami chciałoby wycofać się z restrykcyjnej polityki klimatycznej UE, która dla skali globalnej nie ma znaczenia ${ }^{11}$. Dla gospodarki UE oznacza to większe uzależnienie od rynku zewnętrznego, co dodatkowo wykazuje sprzeczność dla jednoczesnej realizacji celu ograniczania emisji dwutlenku węgla i zmniejszenia uzależnienia od dostaw zewnętrznych.

Tendencje w strukturze zużywanych źródeł energii potwierdzają również światowe prognozy.

\footnotetext{
${ }^{10} \mathrm{http}: / /$ www.biztok.pl/czy-ropa-zaczyna-tracic-swoja-dominujaca-pozycje-w-swiecie [dostęp 11.12.2014].

${ }^{11} \mathrm{http}: / /$ fsrpolicybriefs.eu [dostęp 11.12.2014].
} 


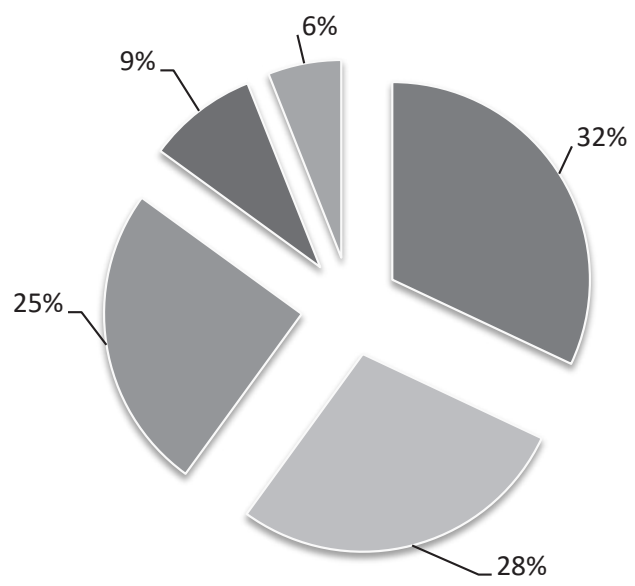

Wegiel

Ropa naftowa

- Gaz ziemny

- OZE (wraz z hydroenergetyką - 5\%)

Energia jądrowa

Rysunek 8. Prognoza struktury zużywanej energii pierwotnej dla roku 2030 (\%)

Źródło: opracowanie własne na podstawie International Energy Agency, Key World Energy Statistics 2014.

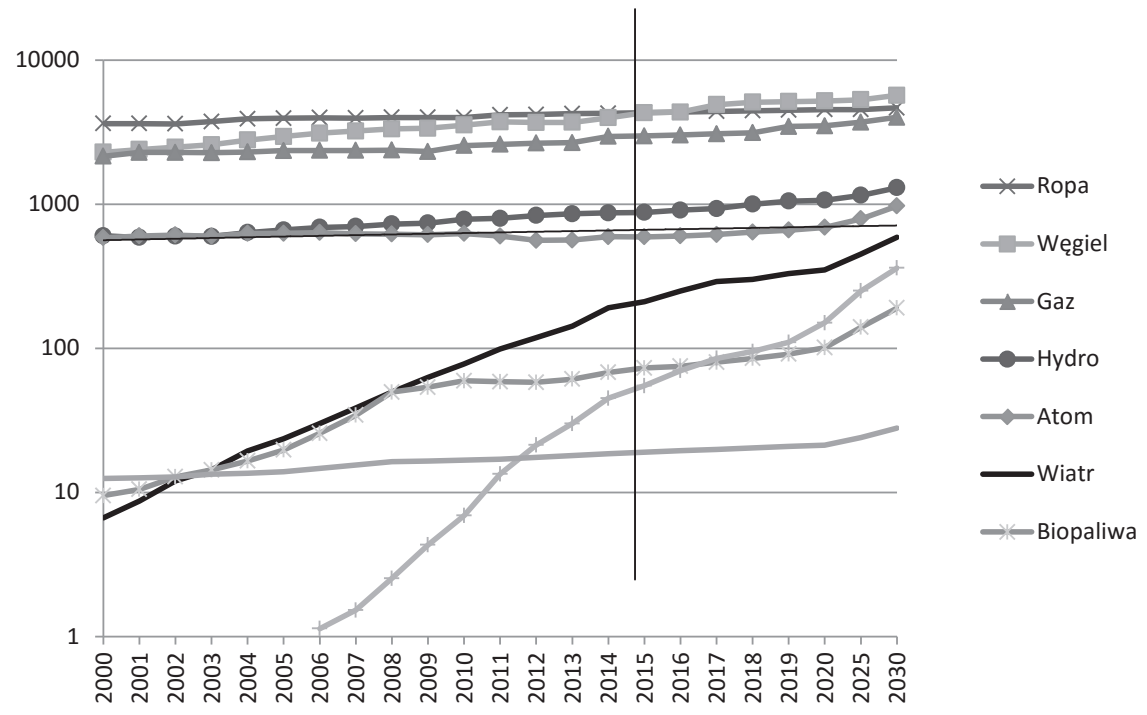

Rysunek 9. Konsumpcja energii według źródła wraz z prognozą do 2030 roku (Mtoe)

Źródło: Statistical Review of World Energy 2014, http://www.bp.com/en/global/energy-economics/statisticalreview-of-world-energy.html [dostęp 18.02.2015]. 


\section{Podsumowanie}

W globalnej rzeczywistości z powyższych prognoz wynika, że w perspektywie roku 2030 nie nastąpią zasadnicze zmiany w strukturze wykorzystania źródeł energii poza powrotem węgla na pozycję lidera. Do szerokiego wykorzystania najbardziej zasobnego i równomiernie występującego na świecie surowca energetycznego, jakim jest węgiel, przyczynią się również możliwości wykorzystania go jako surowca chemicznego i paliwa transportowego. W kolejnych latach XXI wieku ogromne znaczenie dla sytuacji energetycznej na świecie będą miały badania i rozwój nowych technologii pozyskiwania energii. Przykładowo rozwój czystych technologii węglowych jest związany z koniecznością osiągnięcia lepszej sprawności energetycznej wykorzystania węgla, jak również uzyskania lepszej efektywności ekonomicznej. Powstaje w związku z tym konieczność przystąpienia do wypracowania bardziej racjonalnych i wysokosprawnych technologii jego wykorzystania. We wszystkich scenariuszach w nadchodzących dziesięcioleciach paliwa kopalne nadal będą odgrywać dominującą rolę. Spadek cen energii odnawialnej doprowadzi do stopniowego wprowadzania czystych energii, ale przebudowa światowego systemu energetycznego stanowi trudne, a przede wszystkim obecnie zbyt kosztowne zadanie. Dlatego nawet w 2050 roku żaden z czterech głównych scenariuszy rozwoju energetyki światowej wymodelowanych przez IPCC nie ukazuje znaczących wartości korzystania z dostępnych źródeł energii odnawialnej ${ }^{12}$.

\section{Literatura}

Dyer H., Trombetta M.J., International Handbook of Energy Security, Edward Elgar, Cheltenham 2013.

Enerdata, Global Energy Statistical Yearbook 2014.

Energy Information Administration, International Energy Annual, 2014.

Leveque L.F., Glachant J.M., Barquin J., Holz F., Nuttall W., Security of energy supply in Europe Natural Gas, Nuclear and Hydrogen, Loyola de Palacio series on European Energy Policy, 2014.

Moran D., Russell J., Energy Security and Global Politics, Routledge Global Security Studies, Taylor \& Francis Group, London and New York 2009.

Prognozy dla globalnego rynku energetycznego, ed. H. Thaler, Frost \& Sullivan, 2014. Statistical Review of World Energy 2013 i 2014.

\footnotetext{
${ }^{12}$ T. Sznerch, http://www.nature.com/news/2011/full/a.html [dostęp 22.12.2014].
} 
Źródła internetowe

http://ec.europa.eu/energy/statistics

http://europa.eu/legislation_summaries/energy/index_pl.htm

http://fsrpolicybriefs.eu

http://jaron.salon24.pl/jeden-wybuch-wulkanu-i-mit-o-szkodliwosci-co2-i-emisji-pyluupadl

http://www.nature.com/news/2011/full/a.html

http://szczesniak.pl

www.calgaryherald.com

www.who.int/publications/en

\title{
THE SITUATION IN THE GLOBAL ENERGY MARKET AND OUTLOOK TO 2030
}

\begin{abstract}
Progressive globalization processes and the associated solutions internationally are subject to incredible dynamics. One of the fundamental areas of modern political economy are solutions for energy sources. In this paper based on statistical data analysis and inference has been made of the current state of energy markets and attempt to scratch the development prospects of the global energy market by 2030, with a particular focus on the situation of European countries.
\end{abstract}

Translated by Ireneusz Miciuła

Keywords: energy resources, political economy, sustainable development, international finance

JEL codes: A11, E01, E66, F00, F18, G15 
